Article

\title{
Production of Bio-Oils and Biochars from Olive Stones: Application of Biochars to the Esterification of Oleic Acid
}

\author{
Francisco José Sánchez-Borrego $\mathbb{D}^{\mathrm{D}}$, Tomás Juan Barea de Hoyos-Limón, Juan Francisco García-Martín *iD \\ and Paloma Álvarez-Mateos*D
}

check for

updates

Citation: Sánchez-Borrego, F.J.; Barea de Hoyos-Limón, T.J.; García-Martín, J.F.; Álvarez-Mateos, P. Production of Bio-Oils and Biochars from Olive Stones: Application of Biochars to the Esterification of Oleic Acid. Plants 2022, 11, 70. https://doi.org/ $10.3390 /$ plants 11010070

Academic Editor:

Georgios Koubouris

Received: 2 December 2021

Accepted: 23 December 2021

Published: 27 December 2021

Publisher's Note: MDPI stays neutral with regard to jurisdictional claims in published maps and institutional affiliations.

Copyright: (C) 2021 by the authors. Licensee MDPI, Basel, Switzerland. This article is an open access article distributed under the terms and conditions of the Creative Commons Attribution (CC BY) license (https:// creativecommons.org/licenses/by/ $4.0 /)$.
Departamento de Ingeniería Química, Facultad de Química, Universidad de Sevilla, 41012 Seville, Spain; fsanchez25@us.es (F.J.S.-B.); tbareadehoyoslimn@gmail.com (T.J.B.d.H.-L.)

* Correspondence: jfgarmar@us.es (J.F.G.-M.); palvarez@us.es (P.Á.-M.)

\begin{abstract}
Olive stones are a by-product of the olive oil industry. In this work, the valorisation of olive stones through pyrolysis was attempted. Before pyrolysis, half of the samples were impregnated with sulphuric acid. Pyrolysis was carried out in a vertical tubular furnace with a ceramic support. The pyrolysis conditions assayed were: temperature between 400 and $600{ }^{\circ} \mathrm{C}$, heating ramp between 5 and $20^{\circ} \mathrm{C} \cdot \mathrm{min}^{-1}$, and inert gas flow rate between 50 and $300 \mathrm{~mL} \mathrm{Ar} \cdot \mathrm{min}^{-1}$. Among them, temperature was the only parameter that influenced the pyrolysis product distribution. The most suitable temperature for obtaining biochar was $400{ }^{\circ} \mathrm{C}$ for both non-treated and pre-treated raw material, while for obtaining bio-oil, it was $600{ }^{\circ} \mathrm{C}$ for impregnated olive stones and $400{ }^{\circ} \mathrm{C}$ for the raw material. The impregnated olives stones led to bio-oils with much higher amounts of highadded-value products such as levoglucosenone and catechol. Finally, the biochars were impregnated with sulphuric acid and assayed as biocatalysts for the esterification of oleic acid with methanol in a stirred tank batch reactor at $60^{\circ} \mathrm{C}$ for $30 \mathrm{~min}$. Biochars from non-treated olive stones, which had lower specific surfaces, led to higher esterification yields (up to $96.2 \%$ ).
\end{abstract}

Keywords: biodiesel; bio-oil; levoglucosenone; olive stones; pyrolysis

\section{Introduction}

The agricultural exploitation of olive tree accounts for $11 \times 10^{6}$ ha in the world, most of them in Mediterranean countries, for example, Spain, Italy, Greece, Morocco, etc. As a result, $20 \times 10^{6} \mathrm{t}[1]$ olives a year are produced worldwide. The main exploitation is the production of olive oil, which produces large amounts of by-products. Another main products of olives are table olives, known throughout the world as pickles and used as an ingredient in cooking.

In some olive oil companies, the olives are first de-stoned before entering the olive oil extraction system, in which the olives go through a decanter of two or three outlets to obtain olive oil and pomace (containing $65-75 \mathrm{wt} . \%$ moisture), or olive oil, pomace (containing $45-55$ wt.\% moisture), and wastewater, respectively [1,2]. This work focuses mainly on olive stones (OS), which have an estimated production of 42,900 t/year in Spain [3].

OS are made up of cellulose, hemicellulose, and lignin. Their composition of these components is different depending on the olive variety, ranging between 27.1 and $36.4 \mathrm{wt} . \%$ of cellulose; 24.5 and $32.2 \mathrm{wt} . \%$ of hemicellulose, and 23.1 and $40.4 \mathrm{wt} . \%$ of lignin [1,4-6].

One of the potential uses of OS is the production of renewable energy through their biochemical transformation into biofuels (bioethanol) [7]. Furthermore, they could be used as a lightweight aggregate in construction mortars [8], as a feed flour with high protein, fibre, and omega-3 content [9], and as a bioplastic precursor [10].

However, the most frequent use of this by-product is combustion to obtain thermal energy. Its high calorific value and low cost make olive stones an excellent lignocellulosic material for energy. Combustion generates pollution for the environment, emitting gases 
such as $\mathrm{CO}_{2}, \mathrm{CO}, \mathrm{SO}, \mathrm{SO}_{2}$, and polycyclic aromatic hydrocarbons. There are alternative processes, less harmful in their use, for specific other thermochemical treatments such as pyrolysis, torrefaction, and gasification [11].

Pyrolysis is a thermochemical process carried out at high temperatures, between 400 and $700{ }^{\circ} \mathrm{C}$, under an inert atmosphere (total absence of oxygen). During the pyrolysis process, each lignocellulose material undergoes different reaction mechanisms (that is, decarboxylation, dehydration, and demethylation) resulting in the production of bio-oil, syngas, and biochar [12].

In addition to the characteristics of the raw material used, there are several factors that influence the process, namely temperature, heating ramp, and gas flow rate [13]. It is important to note the effect of temperature on obtaining of pyrolysis products, since higher percentages of bio-oil are obtained at high temperatures $\left(500-700{ }^{\circ} \mathrm{C}\right)$, while a higher proportion of biochar is obtained at low temperatures $\left(350-400{ }^{\circ} \mathrm{C}\right)[14]$.

Pyrolysis can be fast or slow, depending on the heating ramp and residence time. Lower process temperatures and heating ramps and longer gas residence times improve biochar production. Approximately $35 \%$ of the weight of dry biomass can be turned into biochar, although higher pressure can provide significantly higher performance [15].

Bio-oil is a mixture of organic compounds such as esters, acids, and aromatic compounds depending on the composition of the raw material; thus, research has been carried out in recent years on the use of these components. One of these applications is the extraction of some aromatic components, such as phenols, and other compounds of high added value such as levoglucosenone or catechol. Furthermore, it is important to mention that bio-oil is also used for the manufacture of high-quality biofuels for internal combustion engines [16]. However, no information can be found in the available literature on the composition of bio-oils from olive stones.

Non-condensable gases (syngas) are a mixture of basic components such as carbon monoxide $(\mathrm{CO})$ and hydrogen $\left(\mathrm{H}_{2}\right)$. The higher heating value of syngas $\left(4.37-5.68 \mathrm{MJ} / \mathrm{m}^{3}\right)$ plays an important role in the generation of energy in cogeneration plants [17].

Biochar is a non-volatile carbon-rich solid residue composed of the non-hydrocarbon residues of biomass, mainly parts of lignin, oxides (usually metallic), and heavy metals, depending on the composition of the feedstock. Among all the applications that biochar currently has, its use as a catalyst can be highlighted, for example, in the esterification reaction of oleic acid with methanol to obtain biodiesel $[18,19]$. Many researchers have found that biochar can be used as an alternative adsorbent to remove different types of pollutants, such as heavy metals, nutrients, and pharmaceuticals, from aqueous solutions [20]. Many raw materials and their resulting biochars have low specific surface or low catalytic activity, so these materials are pre-treated (activated) with acids, such as sulphuric acid [21] or phosphoric acid [22]. To the best of our knowledge, biochars from olives stones have not been applied as biocatalyst so far.

Based on all the considerations mentioned above, the objectives of this work were as follows:

- Valorise olive stones through pyrolysis;

- Assess the most suitable pyrolysis conditions for the production of biochar and bio-oil;

- Characterize the biochars and bio-oils obtained;

- Establish the most suitable conditions for obtaining levoglucosenone and catechol in bio-oils;

- Apply the biochar obtained under the most suitable pyrolysis conditions as a biocatalyst for the esterification reaction of free fatty acids with methanol to obtain biodiesel. 


\section{Results}

\subsection{Characterisation of the Raw Material}

\subsubsection{Thermogravimetric Analysis (TGA)}

The OS were analysed by thermogravimetry using the thermobalance under the conditions described in Section 3.4.1 in order to study their decomposition and obtain information on the optimum carbonisation temperature.

Figure 1 shows the different peaks corresponding to the mass loss during heating. Mass loss at temperatures around $100{ }^{\circ} \mathrm{C}$ was associated with moisture content. In this case, the loss occurred around $70{ }^{\circ} \mathrm{C}$, with a total loss of $15 \mathrm{wt} . \%$, corresponding to physically adsorbed water that interacts only with other water molecules, a band that extended up to $120{ }^{\circ} \mathrm{C}[23]$.

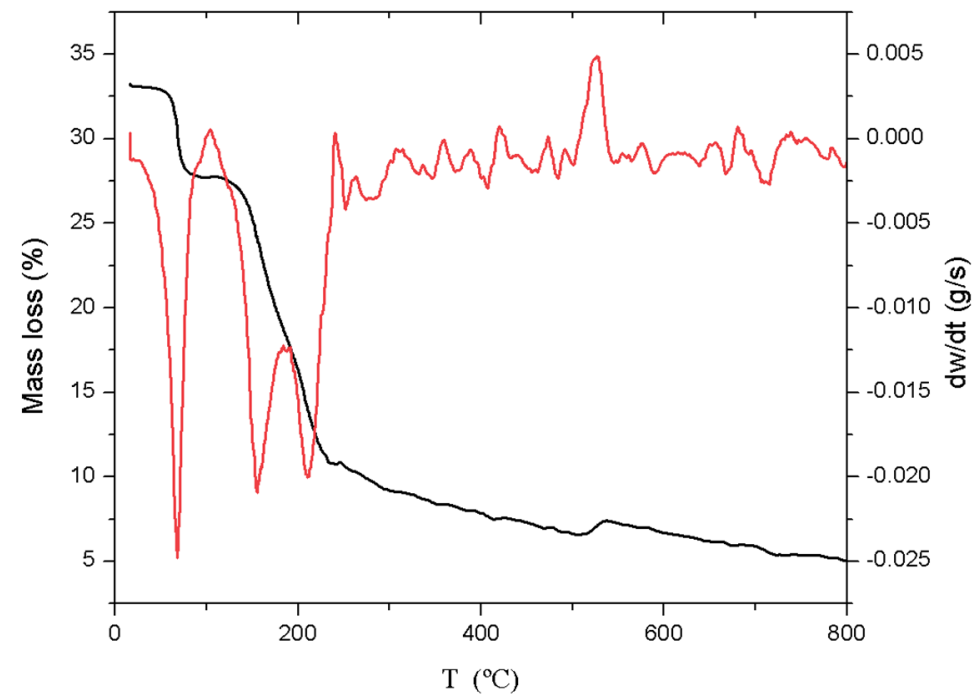

Figure 1. TG (black line) and DTG (red line) curves obtained from the carbonisation of OS.

Cellulose polymers degraded between 150 and $200{ }^{\circ} \mathrm{C}$ [24], and in this case showed a maximum degradation rate at $165^{\circ} \mathrm{C}$, as observed in the peak of the DTG curve. This loss was $24 \%$ of the total weight of the sample.

On the other hand, degradation of hemicellulose was observed from 200 to $250{ }^{\circ} \mathrm{C}$ [24], accounting for $27 \mathrm{wt} . \%$ of the sample.

In Figure 1, lignin did not show a well-defined degradation peak. On the contrary, the degradation process started at $200{ }^{\circ} \mathrm{C}$ and continued gradually up to $800{ }^{\circ} \mathrm{C}$, a temperature at which more than $80 \mathrm{wt} . \%$ of the initial mass had been decomposed [24], corresponding to approximately $15 \mathrm{wt} . \%$ of the total weight of the raw material.

As can be seen in the TGA, a large part of the weight loss (70\%) had already occurred at $400{ }^{\circ} \mathrm{C}$ (Figure 1), which indicated that the sample consisted mainly of water, cellulose, and hemicellulose. It was also observed that $80 \mathrm{wt} \%$ degradation of the initial mass was reached at $600{ }^{\circ} \mathrm{C}$. Therefore, either of the two maximum temperatures assayed in the pyrolysis process ensured the carbonisation of most of the olive stones.

Finally, at $800{ }^{\circ} \mathrm{C}$, there was still around $20 \mathrm{wt} . \%$ of the olive stones undegraded by pyrolysis, which corresponds to carbon residues and metallic compounds.

When comparing these data with previous work carried out with OS [25], it could be seen that the product yield was very similar. Cellulose and lignin yields were lower (24.0 vs. $26.8 \mathrm{wt} \%$. and 15.0 vs. $20.0 \mathrm{wt}$ \%, respectively), but that of hemicellulose was higher (27.0 vs. 25.5 wt. $\%)$. 


\subsubsection{FTIR Analysis}

The FTIR spectra of OS pre-treated with sulphuric acid $\left(\mathrm{OS}+\mathrm{H}_{2} \mathrm{SO}_{4}\right)$ were compared with those of the non-treated raw material (OS), with the purpose of evaluating the influence of this pre-treatment on the structure (Figure 2).
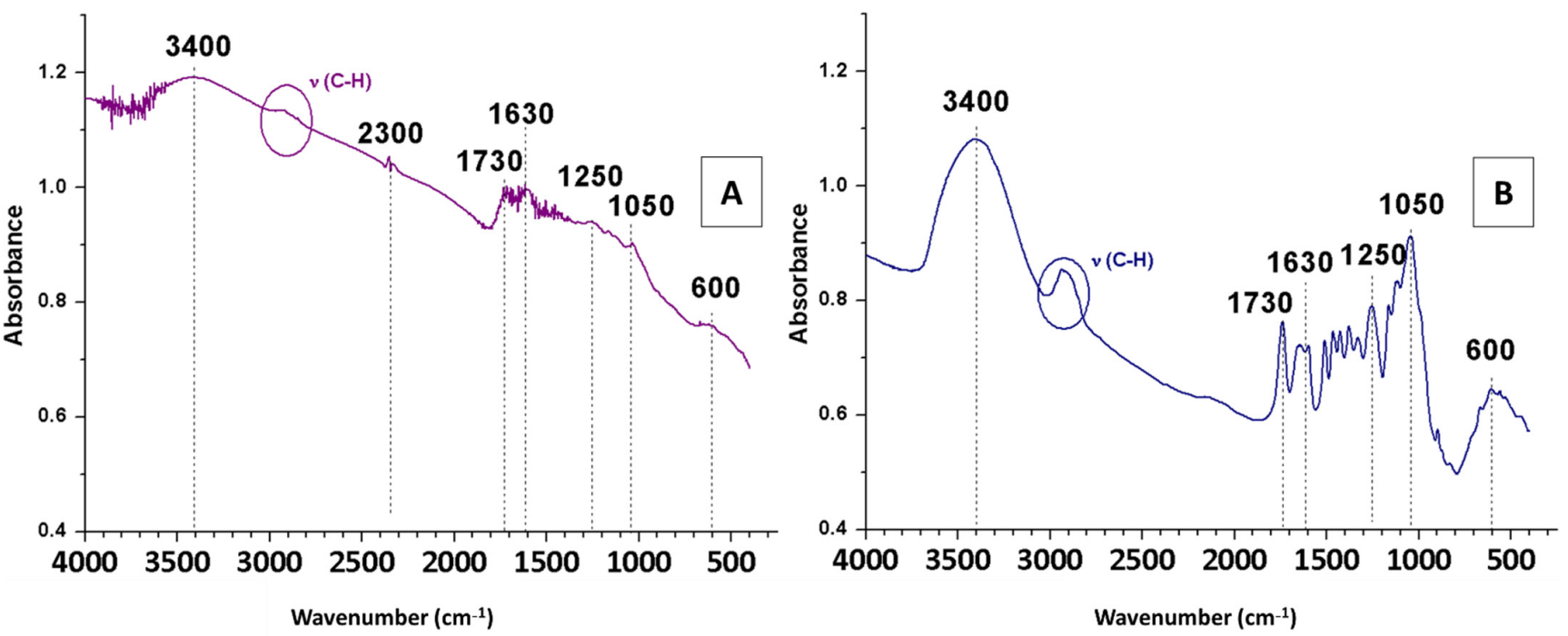

Figure 2. FTIR spectra of $\mathrm{OS}+\mathrm{H}_{2} \mathrm{SO}_{4}(\mathbf{A})$ and $\mathrm{OS}$ (B).

The spectrum of OS $+\mathrm{H}_{2} \mathrm{SO}_{4}$ (Figure 2A) showed differences in most bands compared to the FTIR spectrum or the raw material (Figure 2B). This was explained by the fact that sulphuric acid degraded hemicellulose and cellulose, which could be seen in the $3500-3100 \mathrm{~cm}^{-1}$ bands corresponding to $\mathrm{OH}$ vibrations (due to the presence of cellulose and hemicellulose with their abundant alcoholic hydroxyl groups or the symmetric and asymmetric stretching vibrations related to $\mathrm{H}_{2} \mathrm{O}$ molecules) and in the aliphatic bands around $2900 \mathrm{~cm}^{-1}$. The band at $2300 \mathrm{~cm}^{-1}$ corresponded to the asymmetric tension vibration of the $\mathrm{CO}_{2}$ molecule, which was higher in intensity in the spectrum of OS $+\mathrm{H}_{2} \mathrm{SO}_{4}$ compared to that of OS. Regarding the band at $1730 \mathrm{~cm}^{-1}$, it had a lower intensity with pre-treatment (Figure 2A) than without pre-treatment (Figure 2B), due to the degradation of hemicellulose by sulphuric acid. Furthermore, sulphuric acid degraded not only hemicellulose and cellulose, but also lignin. Although lignin degradation was lower, it can be seen reflected in the $\mathrm{C}=\mathrm{C}$ bands (at $1630 \mathrm{~cm}^{-1}$ ), which are characteristic of lignin aromatics [23]. Since the bands at 1250 and $1050 \mathrm{~cm}^{-1}$ were related to glycosidic bonds (found mainly in hemicellulose and cellulose), their intensity was greatly reduced after treatment. Finally, the band at $600 \mathrm{~cm}^{-1}$, characteristic of calcium, remained completely unchanged.

\subsection{Pyrolysis Yields}

Table 1 shows the yield of each product obtained in the different pyrolysis processes according to the operational conditions.

Regarding the pyrolysis temperature, it was inversely proportional to the biochar production (Table 1), but directly proportional to the fluent products (biogas and bio-oil) [26].

Regarding the heating ramp, pyrolysis from $\mathrm{OS}+\mathrm{H}_{2} \mathrm{SO}_{4}$ led to the same biochar yield. However, modifying the heating ramp achieved a reduction in the pyrolysis process time while leading to the same biochar yield, that is, the use of a heating ramp of $20^{\circ} \mathrm{C} \cdot \mathrm{min}^{-1}$ resulted in time savings of $20 \mathrm{~min}$ and $1 \mathrm{~h}$ when compared to the use of heating ramps of 10 and $5{ }^{\circ} \mathrm{C} \cdot \mathrm{min}^{-1}$, respectively. In addition, the reduction of the pyrolysis process time also resulted in energy savings, with $20^{\circ} \mathrm{C} \cdot \mathrm{min}^{-1}$ being the optimal heating ramp. Similarly, the resulting percentages of biochar were again similar in the pyrolysis of OS. However, the influence on bio-oil should be highlighted, because the lower the heating ramp, the higher 
the bio-oil yield. Therefore, $5^{\circ} \mathrm{C} \cdot \mathrm{min}^{-1}$ is the optimal heating ramp when the objective is to obtain bio-oil.

Table 1. Biochar, syngas, and bio-oil yields obtained under different pyrolysis conditions.

\begin{tabular}{|c|c|c|c|c|c|c|c|c|}
\hline Pyrolysis & $\begin{array}{c}\text { Raw } \\
\text { Material }\end{array}$ & $\begin{array}{l}\text { SAT } \\
(\mathrm{min})\end{array}$ & $\begin{array}{c}\mathrm{T} \\
\left({ }^{\circ} \mathrm{C}\right)\end{array}$ & $\begin{array}{c}\mathrm{H}_{\text {ramp }} \\
\left({ }^{\circ} \mathrm{C} \cdot \text { min }^{-1}\right)\end{array}$ & $\begin{array}{c}\text { Ar Flow } \\
\left(\mathrm{mL} \cdot \mathrm{min}^{-1}\right)\end{array}$ & $\begin{array}{l}Y_{\text {Biochar }} \\
\text { (wt.\%) }\end{array}$ & $\begin{array}{l}Y_{\text {syngas }} \\
\text { (wt.\%) }\end{array}$ & $\begin{array}{l}Y_{\text {Bio-oil }} \\
\text { (wt.\%) }\end{array}$ \\
\hline 1 & $\mathrm{OS}+\mathrm{H}_{2} \mathrm{SO}_{4}$ & 4 & 600 & 10 & 150 & 44.6 & 38.2 & 17.1 \\
\hline 2 & $\mathrm{OS}+\mathrm{H}_{2} \mathrm{SO}_{4}$ & 4 & 500 & 10 & 150 & 51.2 & 35.2 & 13.5 \\
\hline 3 & $\mathrm{OS}+\mathrm{H}_{2} \mathrm{SO}_{4}$ & 4 & 400 & 10 & 150 & 57.8 & 35.6 & 6.7 \\
\hline 4 & $\mathrm{OS}+\mathrm{H}_{2} \mathrm{SO}_{4}$ & 4 & 400 & 5 & 150 & 59.6 & 33.4 & 7.0 \\
\hline 5 & $\mathrm{OS}+\mathrm{H}_{2} \mathrm{SO}_{4}$ & 4 & 400 & 20 & 150 & 60.2 & 31.6 & 8.2 \\
\hline 6 & $\mathrm{OS}+\mathrm{H}_{2} \mathrm{SO}_{4}$ & 8 & 400 & 10 & 150 & 60.0 & 33.0 & 7.0 \\
\hline 7 & $\mathrm{OS}+\mathrm{H}_{2} \mathrm{SO}_{4}$ & 8 & 400 & 20 & 300 & 57.2 & 41.2 & 1.6 \\
\hline 8 & $\mathrm{OS}+\mathrm{H}_{2} \mathrm{SO}_{4}$ & 8 & 400 & 20 & 50 & 57.8 & 37.3 & 4.9 \\
\hline 9 & $\mathrm{OS}+\mathrm{H}_{2} \mathrm{SO}_{4}$ & 8 & 600 & 10 & 150 & 50.0 & 47.4 & 2.6 \\
\hline 10 & OS & - & 600 & 10 & 150 & 27.2 & 52.6 & 20.3 \\
\hline 11 & OS & - & 500 & 10 & 150 & 27.7 & 48.8 & 23.5 \\
\hline 12 & OS & - & 400 & 10 & 150 & 31.2 & 45.5 & 23.4 \\
\hline 13 & OS & - & 400 & 20 & 150 & 29.3 & 40.5 & 30.2 \\
\hline 14 & OS & - & 400 & 20 & 50 & 29.7 & 29.5 & 40.8 \\
\hline 15 & OS & - & 400 & 5 & 150 & 31.7 & 36.2 & 32.2 \\
\hline 16 & OS & - & 400 & 5 & 50 & 33.5 & 30.3 & 36.2 \\
\hline 17 & OS & - & 400 & 5 & 300 & 30.3 & 44.3 & 25.3 \\
\hline
\end{tabular}

Furthermore, in terms of argon flow rate, the pyrolysis of $\mathrm{OS}+\mathrm{H}_{2} \mathrm{SO}_{4}$ under $150 \mathrm{~mL} \mathrm{Ar} \cdot \mathrm{min}^{-1}$ produced the highest amounts of biochar and bio-oil. When OS was used as raw material (without sulphuric acid pre-treatment), there were hardly any differences in the yields of pyrolysis products when the argon flow rate was varying. Pyrolysis under $50 \mathrm{~mL} \mathrm{Ar} \cdot \mathrm{min}^{-1}$ should be highlighted, as it was the one that achieved the highest biochar and bio-oil yields from non-treated OS, as well as the lowest Ar expenditure.

Finally, in light of these data (Table 1), it could be said that feedstock that was previously pre-treated ( $\mathrm{OS}+\mathrm{H}_{2} \mathrm{SO}_{4}$ ) led to higher biochar yields. These higher biochar yields are due to the formation of chemical bonds between two polymer chains (cross-link) and the retention of low-molecular-weight carbonaceous species in the solid phase, stabilising the cellulose structure [27]. The results showed that acid pre-treatment resulted in $60 \%$ of biochar yield, compared to only about $31 \%$ of biochar yield without pre-treatment [28].

Pyrolyses 1 and 9 and Pyrolyses 3 and 6 were performed under the same conditions, respectively (Table 1). However, the product yields showed some differences even though the OS were from the same batch. This is because two pre-treatments were performed at different times during the execution of the experiments in this research. The first involved the first to the fifth samples, while the second involved from the sixth to the ninth samples.

These differences were based on the sulphuric actuation time (4 vs. $8 \mathrm{~min}$ ) in the pre-treatment with sulphuric acid. The longer the residence time, the greater the retention of carbonaceous biomass, which had a direct influence on product yields (Table 1), as the longer the contact time with $\mathrm{H}_{2} \mathrm{SO}_{4}$, the higher the biochar yield [27].

\subsection{Bio-Oil Characterisation}

The bio-oils were subjected to gas chromatography-mass spectroscopy analysis in order to obtain a qualitative and semi-quantitative analysis of the major compounds. The samples selected were those from Pyrolyses 3 and 12, as they were obtained from pyrolysis under the same conditions, but with different raw material. Specifically, the bio-oil obtained from Pyrolysis 3 was obtained from OS $+\mathrm{H}_{2} \mathrm{SO}_{4}$ and that from Pyrolysis 12 was from OS. Table 2 illustrates the compounds identified by GC-MS, with a probability of matching with the database greater than $40 \%$. 
Table 2. Bio-oils composition.

\begin{tabular}{|c|c|c|}
\hline & \multicolumn{2}{|c|}{ Bio-Oils Samples } \\
\hline & Pyrolysis 3 & Pyrolysis 12 \\
\hline Compound & \multicolumn{2}{|c|}{ Area $(\%)$} \\
\hline Toluene & 1.18 & - \\
\hline Furfural & 5.30 & 3.80 \\
\hline 4-Hydroxy-4-methylpentan-2-one & 2.53 & - \\
\hline 2-Furanmethanol & - & 3.49 \\
\hline Ethylbenzene & 3.03 & 2.34 \\
\hline o-Xylene & 6.26 & 3.40 \\
\hline p-Xylene & 2.74 & 1.51 \\
\hline Cyclopenta-1,2-dione & 1.15 & 2.42 \\
\hline 5-Methyl-2-furancarboxaldehyde & 2.15 & 1.61 \\
\hline Phenol & 3.60 & - \\
\hline N-Butyl-tert-butylamine & - & 2.59 \\
\hline 3-Methylcyclopentan-1,2-dione & - & 2.60 \\
\hline 2-Methylphenol & 1.55 & 1.20 \\
\hline 3-Methylphenol & 3.53 & - \\
\hline 2-Methoxyphenol & 5.28 & 7.87 \\
\hline Levoglucosenone & 9.57 & - \\
\hline Catechol & 6.17 & 3.33 \\
\hline Creosol & 6.94 & 7.32 \\
\hline 1,4:3,6-Dianhydro- $\alpha$-D-glucopyranose & 3.51 & - \\
\hline 3-Methylbenzene-1,2-diol & 1.71 & 1.27 \\
\hline 3-Methoxybenzene-1,2-diol & 2.35 & 3.28 \\
\hline 4-Ethyl-2-methoxyphenol & 2.14 & 5.02 \\
\hline 4-Methylbenzene-1,2-diol & 1.59 & 1.55 \\
\hline 2-Methoxy-4-vinylphenol & 5.38 & 14.30 \\
\hline Eugenol & - & 2.00 \\
\hline Vanillin & 3.65 & 1.50 \\
\hline 3,5-Dimethoxy-4-hydroxytoluene & 6.07 & 5.70 \\
\hline Trans-isoeugenol & - & 5.75 \\
\hline 1,6 -Anhydro- $\beta$-D-glucopyranose & 2.88 & 1.51 \\
\hline 5-Tert-butylpyrogallol & 1.73 & - \\
\hline 1-(4-Hydroxy-3-methoxyphenyl)-propan-2-one & 1.52 & 2.02 \\
\hline 4-Ethanoyl-2,6-dimethoxy-phenol & - & 3.56 \\
\hline Butyrovanilone & 3.15 & - \\
\hline 4-Hydroxy-3,5-dimethoxy-benzaldehyde & 1.73 & - \\
\hline (E)-2,6-Dimetoxi-4-(prop-1-en-1-il)-fenol & - & 4.56 \\
\hline Coniferyl aldehyde & - & 2.15 \\
\hline Syringylacetone & - & 2.37 \\
\hline Butylsyringone & 1.64 & - \\
\hline
\end{tabular}

The influence of OS pre-treatment on the bio-oil composition can be observed in Table 2. Some of the compounds found in the bio-oil produced from $\mathrm{OS}+\mathrm{H}_{2} \mathrm{SO}_{4}$ are more valuable than those obtained from OS, such as levoglucosenone, catechol, or vanillin. This could be explained by the transformation of lignocellulosic compounds into levoglucosenone under acidic conditions [29-31].

Levoglucosenone was one of the most abundant compounds in the bio-oil obtained from the pyrolysis of pre-treated OS, accounting for almost $10 \%$ of the bio-oil. This compound has a high market value: $10 \mathrm{mg}$ of levoglucosenone $(95 \%)$ as a laboratory reagent currently cost 165 euros (Sigma Aldrich, St Louis, MO, USA, 11/2021).

\subsection{Biochar Characterisation}

FTIR spectroscopy was used for the analysis of the surface functional groups in the biochars obtained under different conditions (acid pre-treatment, temperature, heating ramp, and argon flow rate). 


\subsubsection{Temperature Influence}

In order to assess the effect of temperature, the FTIR spectra of the raw materials (OS $+\mathrm{H}_{2} \mathrm{SO}_{4}$ and $\mathrm{OS}$ ) were compared with those of the biochars obtained from them at different maximum pyrolysis temperatures, keeping the rest of the conditions constant $\left(150 \mathrm{~mL} \mathrm{Ar} \cdot \mathrm{min}^{-1}\right.$ and $\left.10^{\circ} \mathrm{C} \cdot \mathrm{min}^{-1}\right)$ (Figure 3$)$.

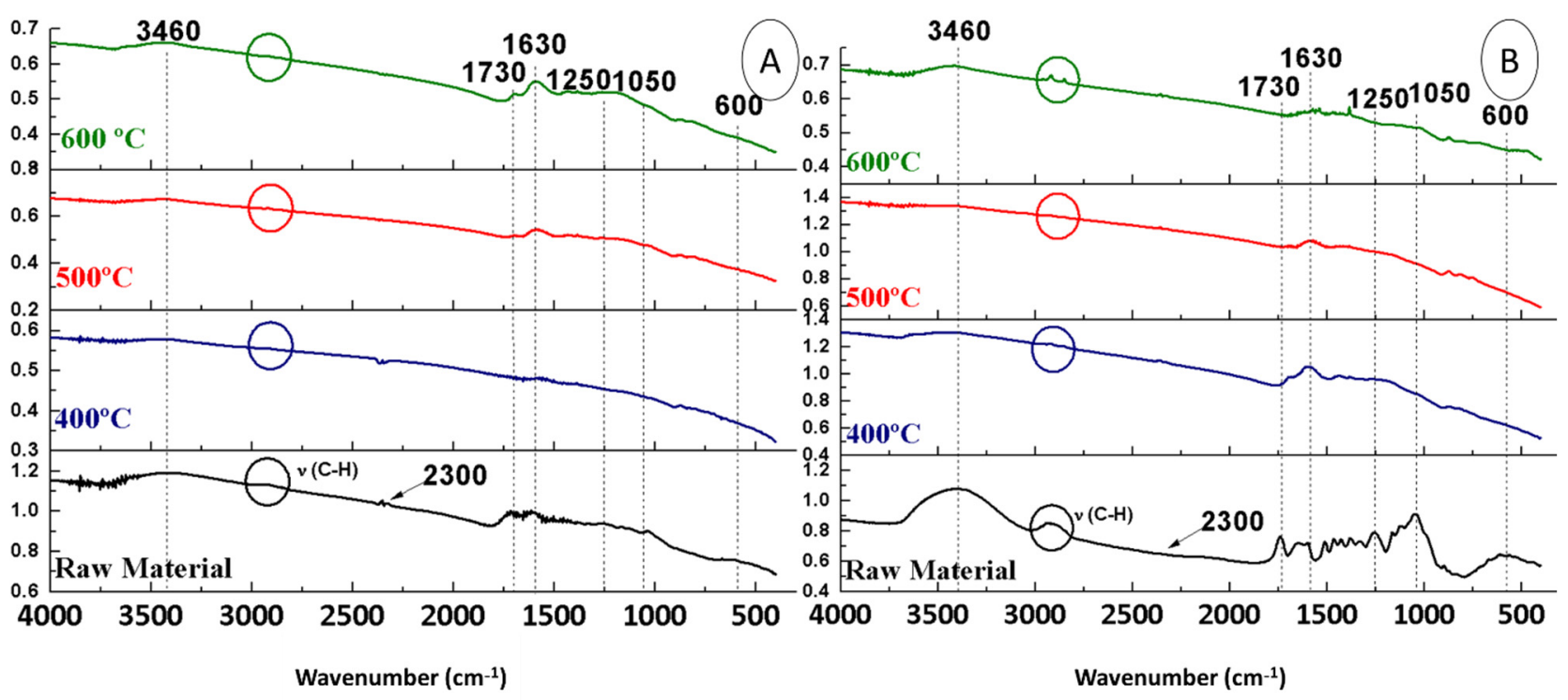

Figure 3. FTIR spectra of biochars from $\mathrm{OS}+\mathrm{H}_{2} \mathrm{SO}_{4}(\mathbf{A})$ and $\mathrm{OS}(\mathbf{B})$ at different temperatures.

The first band observed in both Figure $3 \mathrm{~A}, \mathrm{~B}$ was at $3400 \mathrm{~cm}^{-1}$. This is usually associated with water absorption ( $\mathrm{OH}$ vibration), which is explained by the fact that the analysis was carried out under ambient conditions (with humidity in the atmosphere).

Regarding the $\mathrm{OS}+\mathrm{H}_{2} \mathrm{SO}_{4}$ biochars (Figure 3A), it could be seen that at $600{ }^{\circ} \mathrm{C}$ there were no traces of aliphatic hydrocarbons $\left(2900 \mathrm{~cm}^{-1}\right)$. The band at $2300 \mathrm{~cm}^{-1}$ $\left(\mathrm{CO}_{2}\right)$ appeared only at $400{ }^{\circ} \mathrm{C}$. On the contrary, the bands at $1730 \mathrm{~cm}^{-1}(\mathrm{C}=\mathrm{O})$ and $1630 \mathrm{~cm}^{-1}(\mathrm{C}=\mathrm{C})$ remained constant and only disappeared when pyrolysed at $400{ }^{\circ} \mathrm{C}$. The peaks observed at 1250 and $1050 \mathrm{~cm}^{-1}$, related to $\mathrm{CO}$ in glycosidic bonds, were inversely proportional to temperature. The aromatic compounds, which appeared at $700-900 \mathrm{~cm}^{-1}$, did not seem affected by the temperature. Finally, the peak at $600 \mathrm{~cm}^{-1}(\mathrm{Ca})$ disappeared completely in the FTIR spectra of biochars from OS $+\mathrm{H}_{2} \mathrm{SO}_{4}$ (Figure 3A).

Regarding the OS biochars (Figure 3B), the band at $2900 \mathrm{~cm}^{-1}$ was only appreciated at the temperature of $600{ }^{\circ} \mathrm{C}$. The band at $2300 \mathrm{~cm}^{-1}\left(\mathrm{CO}_{2}\right)$ was barely appreciated after pyrolysis. When the raw material is pyrolysed at $600 \mathrm{~cm}^{-1}$, the band at $1730 \mathrm{~cm}^{-1}(\mathrm{C}=\mathrm{O})$ and at $1630 \mathrm{~cm}^{-1}(\mathrm{C}=\mathrm{C})$ disappeared completely. While the one at $1250 \mathrm{~cm}^{-1}$ was not influenced by the temperature, the one at $1050 \mathrm{~cm}^{-1}$ was directly proportional to the temperature. In addition, aromatic compounds were present in all biochars (region $700-900 \mathrm{~cm}^{-1}$ ), even at $600{ }^{\circ} \mathrm{C}$. Finally, the peak at $600 \mathrm{~cm}^{-1}$ completely disappeared in all experiments after the pyrolytic treatment.

\subsubsection{Influence of the Heating Ramp}

To assess the effect of the heating ramp, the FTIR spectra of the raw materials (OS + $\mathrm{H}_{2} \mathrm{SO}_{4}$ and OS) were compared with those of the biochars obtained from them at different heating ramps, keeping the rest of the conditions constant $\left(400^{\circ} \mathrm{C}\right.$ and $\left.150 \mathrm{~mL} \mathrm{Ar} \cdot \mathrm{min}^{-1}\right)$ (Figure 4). 


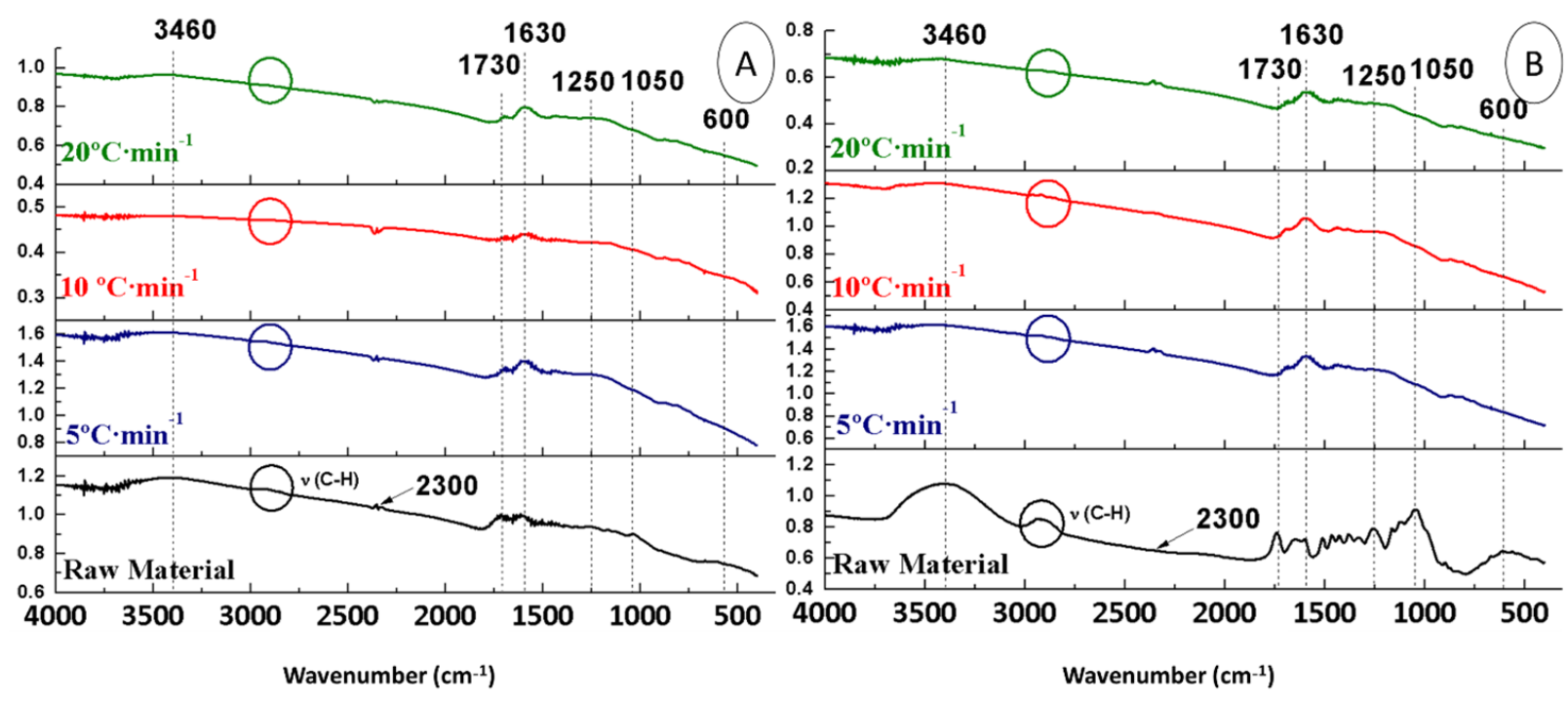

Figure 4. FTIR spectra of biochars from $\mathrm{OS}+\mathrm{H}_{2} \mathrm{SO}_{4}(\mathbf{A})$ and $\mathrm{OS}(\mathbf{B})$ at different heating ramps.

Regarding the $\mathrm{OS}+\mathrm{H}_{2} \mathrm{SO}_{4}$ biochars (Figure $4 \mathrm{~A}$ ), it could be seen that the absorbance band in the $3400 \mathrm{~cm}^{-1}$ region was still present due to absorption of humidity. However, the aliphatic band $\left(2900 \mathrm{~cm}^{-1}\right)$ was not present in the samples. The band at $2300 \mathrm{~cm}^{-1}\left(\mathrm{CO}_{2}\right)$ was kept stable in all samples. The bands at $1730 \mathrm{~cm}^{-1}(\mathrm{C}=\mathrm{O})$ and at $1630 \mathrm{~cm}^{-1}(\mathrm{C}=\mathrm{C})$ still appeared, being lower at $10^{\circ} \mathrm{C} \cdot \mathrm{min}^{-1}$. The peaks observed at 1250 and $1050 \mathrm{~cm}^{-1}$ (CO) disappeared after pyrolysis, so both bands did not rely on the heating ramp. The band at $700-900 \mathrm{~cm}^{-1}$ was kept stable in all the samples. Finally, the peak at $600 \mathrm{~cm}^{-1}$ (Ca) did not change with the heating ramp.

As for OS biochars (Figure 4B), the band at $3400 \mathrm{~cm}^{-1}\left(\mathrm{H}_{2} \mathrm{O}\right)$ remained in all samples. On the contrary, the band at $2900 \mathrm{~cm}^{-1}$ was not present in the samples. The band at $2300 \mathrm{~cm}^{-1}\left(\mathrm{CO}_{2}\right)$ remained stable in all samples. The band at $1730 \mathrm{~cm}^{-1}(\mathrm{C}=\mathrm{O})$ and at $1630 \mathrm{~cm}^{-1}(\mathrm{C}=\mathrm{C})$ remained constant, being lower at $20^{\circ} \mathrm{C} \cdot \mathrm{min}^{-1}$. The bands at 1250 and $1050 \mathrm{~cm}^{-1}$ (CO) disappeared after pyrolysis. There was no influence of the heating ramp on the band at $700-900 \mathrm{~cm}^{-1}$. Finally, the peak at $600 \mathrm{~cm}^{-1}$ (Ca) disappeared completely after pyrolysis.

\subsubsection{Argon Flow Influence}

To assess the effect of the argon flow during pyrolysis, the FTIR spectra of the raw materials (OS $+\mathrm{H}_{2} \mathrm{SO}_{4}$ and $\mathrm{OS}$ ) were compared with those of the biochars obtained at different argon flows, keeping the rest of conditions constant $\left(400{ }^{\circ} \mathrm{C}\right.$ and $20^{\circ} \mathrm{C} \cdot \mathrm{min}^{-1}$ (to $\mathrm{OS}+\mathrm{H}_{2} \mathrm{SO}_{4}$ ) and $5{ }^{\circ} \mathrm{C} \cdot \mathrm{min}^{-1}$ (to OS)) (Figure 5).

Regarding the $\mathrm{OS}+\mathrm{H}_{2} \mathrm{SO}_{4}$ biochars (Figure $5 \mathrm{~A}$ ), it could be seen that the $3400 \mathrm{~cm}^{-1}$ band was still present due to the absorption of water from the atmosphere. However, aliphatic hydrocarbons $\left(2900 \mathrm{~cm}^{-1}\right)$ were not present in the samples. The band at $2300 \mathrm{~cm}^{-1}$ $\left(\mathrm{CO}_{2}\right)$ only appeared at $150 \mathrm{~mL} \mathrm{Ar} \cdot \mathrm{min}^{-1}$. The bands at $1730 \mathrm{~cm}^{-1}(\mathrm{C}=\mathrm{O})$ and at $1630 \mathrm{~cm}^{-1}$ $(\mathrm{C}=\mathrm{C})$ still appeared, being lower at $150 \mathrm{~mL} \mathrm{Ar} \cdot \mathrm{min}^{-1}$. The peaks observed at 1250 and $1050 \mathrm{~cm}^{-1}$ (CO) disappeared after pyrolysis. Aromatic compounds $\left(800 \mathrm{~cm}^{-1}\right)$ did not appear to be affected by argon flow. Finally, the peak at $600 \mathrm{~cm}^{-1}$ due to Ca disappeared completely. 


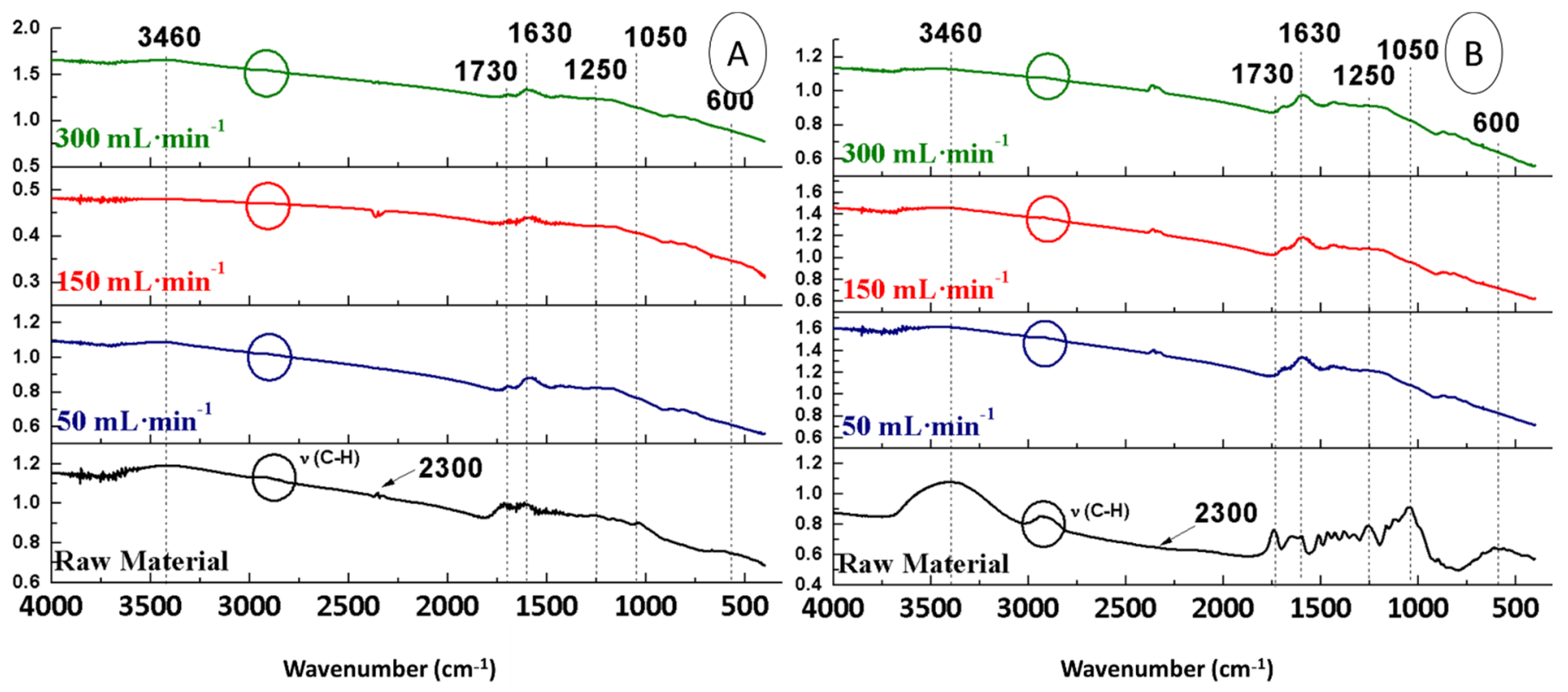

Figure 5. FTIR spectra of biochars from OS $+\mathrm{H}_{2} \mathrm{SO}_{4}(\mathbf{A})$ and $\mathrm{OS}(\mathbf{B})$ at different Ar flows.

Finally, with respect to the OS biochars (Figure 5B), the band at $3400 \mathrm{~cm}^{-1}\left(\mathrm{H}_{2} \mathrm{O}\right)$ remained in all samples. On the contrary, the band at $2900 \mathrm{~cm}^{-1}$ was not present in the samples. The band at $2300 \mathrm{~cm}^{-1}\left(\mathrm{CO}_{2}\right)$ remained stable. The band at $1730 \mathrm{~cm}^{-1}(\mathrm{C}=\mathrm{O})$ and at $1630 \mathrm{~cm}^{-1}(\mathrm{C}=\mathrm{C})$ still occurred, keeping stable in all samples. The bands at 1250 and $1050 \mathrm{~cm}^{-1}$ (CO) disappeared after pyrolysis. Argon flow did not influence aromatic compounds $\left(800 \mathrm{~cm}^{-1}\right)$. Finally, the characteristic peak of calcium $\left(600 \mathrm{~cm}^{-1}\right)$ disappeared completely.

In summary, it could be concluded that the most influential parameter on biochar spectra was the maximum pyrolysis temperature, which is reflected in Section 2.4.1.

\subsubsection{Specific Surface of Biochars}

The specific surface area is an important parameter, as it could influence the use of biochars from OS as a catalyst for esterification reactions. The specific surface area of the biochars obtained under the different pyrolysis conditions is illustrated in Table 3.

It could be observed that the sulphuric pre-treatment of OS increased the specific surface area in biochars. Therefore, all biochars obtained from pyrolysis of OS $+\mathrm{H}_{2} \mathrm{SO}_{4}$ had higher specific surface area than those obtained from OS without pre-treatment under the same conditions. Therefore, the highest BET surface was obtained at $600{ }^{\circ} \mathrm{C}$ with $\mathrm{OS}+$ $\mathrm{H}_{2} \mathrm{SO}_{4}$ as a raw material. 
Table 3. Specific surface of the biochars obtained under different pyrolysis conditions.

\begin{tabular}{|c|c|c|c|c|}
\hline Raw Material & $\begin{array}{c}\mathrm{T} \\
\left({ }^{\circ} \mathrm{C}\right)\end{array}$ & $\begin{array}{c}\mathrm{H}_{\text {ramp }} \\
\left({ }^{\circ} \mathrm{C} \cdot \text { min }^{-1}\right)\end{array}$ & $\begin{array}{l}\text { Ar Flow Rate } \\
\left(\mathrm{mL} \cdot \mathrm{min}^{-1}\right)\end{array}$ & $\begin{array}{c}S_{\text {BET }} \\
\left(\mathrm{m}^{2} \cdot \mathrm{g}^{-1}\right)\end{array}$ \\
\hline $\mathrm{OS}+\mathrm{H}_{2} \mathrm{SO}_{4}$ & 600 & 10 & 150 & 418.60 \\
\hline $\mathrm{OS}+\mathrm{H}_{2} \mathrm{SO}_{4}$ & 500 & 10 & 150 & 263.38 \\
\hline $\mathrm{OS}+\mathrm{H}_{2} \mathrm{SO}_{4}$ & 400 & 10 & 150 & 5.80 \\
\hline $\mathrm{OS}+\mathrm{H}_{2} \mathrm{SO}_{4}$ & 400 & 5 & 150 & 13.75 \\
\hline $\mathrm{OS}+\mathrm{H}_{2} \mathrm{SO}_{4}$ & 400 & 20 & 150 & 21.50 \\
\hline $\mathrm{OS}+\mathrm{H}_{2} \mathrm{SO}_{4}$ & 400 & 10 & 150 & 42.09 \\
\hline $\mathrm{OS}+\mathrm{H}_{2} \mathrm{SO}_{4}$ & 400 & 20 & 300 & 106.11 \\
\hline $\mathrm{OS}+\mathrm{H}_{2} \mathrm{SO}_{4}$ & 400 & 20 & 50 & 52.95 \\
\hline $\mathrm{OS}+\mathrm{H}_{2} \mathrm{SO}_{4}$ & 600 & 10 & 150 & 367.93 \\
\hline OS & 600 & 10 & 150 & 242.70 \\
\hline OS & 500 & 10 & 150 & 230.40 \\
\hline OS & 400 & 10 & 150 & 4.55 \\
\hline OS & 400 & 20 & 150 & 8.18 \\
\hline OS & 400 & 20 & 50 & 3.94 \\
\hline OS & 400 & 5 & 150 & 8.90 \\
\hline OS & 400 & 5 & 50 & 6.57 \\
\hline OS & 400 & 5 & 300 & 12.37 \\
\hline
\end{tabular}

\subsection{Application of Biochars as Biocatalyst for the Esterification Reaction}

The acid index of the commercial oleic acid was $182.18 \mathrm{mg} \mathrm{KOH} / \mathrm{g}$ oil. The acid index was used to follow the reaction. Two phases were obtained: the organic phase (upper phase) composed of methyl esters, and the aqueous phase (lower phase). Table 4 shows the percentage of both phases in each esterification reaction carried out with the different biochars obtained from pyrolysis (activated and non-activated).

Table 4. Resulting acid index, esterification yield, and percentages of organic (OP) and aqueous (AP) phases obtained after esterification.

\begin{tabular}{|c|c|c|c|c|c|}
\hline Biochar & Impregnation & Acid Index & $\begin{array}{c}\text { Esterification } \\
\text { Yield }\end{array}$ & $\begin{array}{l}\text { OP } \\
(\%)\end{array}$ & $\begin{array}{l}\text { AP } \\
(\%)\end{array}$ \\
\hline 1 & No & 172.2 & 5.5 & - & - \\
\hline 2 & No & 180.7 & 0.3 & - & - \\
\hline 4 & Yes & 13.1 & 92.8 & 63.9 & 32.1 \\
\hline 5 & Yes & 16.1 & 91.2 & 64.1 & 22.8 \\
\hline 6 & No & 183.7 & 0.0 & - & - \\
\hline 6 & Yes & 26.7 & 85.3 & 52.1 & 26.9 \\
\hline 7 & Yes & 17.4 & 90.4 & 60.8 & 36.8 \\
\hline 8 & Yes & 12.9 & 92.9 & 58.5 & 26.5 \\
\hline 9 & Yes & 8.8 & 95.2 & 61.0 & 28.5 \\
\hline 10 & Yes & 9.8 & 94.6 & 62.8 & 23.7 \\
\hline 11 & Yes & 7.1 & 96.1 & 55.3 & 25.3 \\
\hline 12 & Yes & 7.0 & 96.2 & 63.7 & 26.6 \\
\hline 13 & Yes & 10.3 & 94.3 & 57.7 & 23.0 \\
\hline 15 & Yes & 8.7 & 95.2 & 49.2 & 28.9 \\
\hline 16 & Yes & 8.4 & 95.4 & 67.3 & 24.8 \\
\hline 17 & Yes & 7.8 & 95.7 & 59.9 & 25.7 \\
\hline
\end{tabular}

The esterification yields obtained were similar to those found in the literature using biochars from the pyrolysis of Jatropha curcas L. [18] and microalgae [19], whose authors reported esterification yields of up to 83.6 and $94.2 \%$, respectively.

The esterifications using the biochars from OS, which had low specific surfaces (Table 3), provided better yields than when using the biochars from OS $+\mathrm{H}_{2} \mathrm{SO}_{4}$ (Table 4). This could be explained by the fact that the lower the specific surface, the larger the pore size. The larger the pore size, the better the absorption of large molecules such as sulphuric 
acid [32]. Furthermore, the pyrolysis temperature at which the biochar was obtained seemed to influence the esterification reaction, with $400{ }^{\circ} \mathrm{C}$ being the optimal temperature to obtain biochars for the esterification reaction.

The organic phase of Experiment 12, which achieved the highest esterification yield $(96.2 \%)$, was analysed as described in Section 3.5.2. In Table 5, the compounds with a probability of matching with the database greater than $40 \%$ were identified, along with their relative area.

Table 5. Composition of the organic phase obtained after esterification of commercial oleic acid.

\begin{tabular}{cc}
\hline Area (\%) & Compound \\
\hline 5.65 & Dodecanoic acid methyl ester \\
2.78 & Methyl myristoleate \\
9.49 & Palmitic acid methyl ester \\
12.79 & Palmitoleic acid methyl ester \\
5.83 & Cis-10-heptadecenoic acid methyl ester \\
48.78 & Oleic acid methyl ester \\
13.50 & Linoleic acid methyl ester \\
1.18 & 11-Eicosenoic acid methyl ester \\
\hline
\end{tabular}

\section{Materials and Methods}

\subsection{Raw Materials}

The OS were provided by the Cooperativa Agrícola Olivarera Virgen del Campo S.C.A. (Cañete de las Torres, Córdoba, Spain). The reagents used were sulphuric acid $\left(\mathrm{H}_{2} \mathrm{SO}_{4}\right)$ 98.0 wt.\% (PanReac, Barcelona, Spain), methanol $\left(\mathrm{CH}_{3} \mathrm{OH}\right) 99.5$ wt.\% (PanReac, Barcelona, Spain), and oleic acid 65.0-88.0 wt.\% (PanReac, Barcelona, Spain). The inert gas used in the pyrolysis was argon (Ar) (Al Air Liquid España, Madrid, Spain).

\subsubsection{Pre-treatment of Olive Stones}

The OS grinding was carried out in a planetary ball mill (Retsch PM 200, Düsseldorf, Germany). The mill was programmed at $500 \mathrm{rpm}$ for $20 \mathrm{~min}$. Grinding was carried out to obtain an OS particle diameter size of less than $150 \mu \mathrm{m}$.

Once all OS were homogenized, a fraction was treated before pyrolysis with $\mathrm{H}_{2} \mathrm{SO}_{4}$. The pre-treatment consisted of pouring $1 \mathrm{~mL}$ of $98 \mathrm{wt} \% \mathrm{H}_{2} \mathrm{SO}_{4}$ per gram of OS, after which it was homogenised and washed with excess distilled water until it had neutral $\mathrm{pH}$ and dried in an oven at $45^{\circ} \mathrm{C}$ for $24 \mathrm{~h}$ to remove moisture. Finally, the mixture was homogenised in a mortar.

\subsection{Pyrolysis}

The OS pre-treated with sulphuric acid and the OS without previous treatment were subjected to pyrolysis under an inert gas atmosphere (Ar) (Figure 6). The pyrolytic furnace (16 cm height, $3.5 \mathrm{~cm}$ diameter) was a vertical tubular furnace with a ceramic support with a pore size of $3 \mathrm{~mm}$. Its maximum temperature is $900{ }^{\circ} \mathrm{C}$ and it is controlled by a CN300-P self-tuning PID controller (Conatec, Irún, Spain).

Between $5 \mathrm{~g}$ of OS pre-treated with $\mathrm{H}_{2} \mathrm{SO}_{4}$ or $6 \mathrm{~g}$ of OS untreated were introduced into the reactor. The temperatures to which the samples were subjected for $2 \mathrm{~h}$ were 400 , 500 , and $600{ }^{\circ} \mathrm{C}$, with heating ramps of 5,10 , and $20^{\circ} \mathrm{C} \cdot \mathrm{min}^{-1}$. Argon flow rates of 50, 150, and $300 \mathrm{~mL} \cdot \mathrm{min}^{-1}$ were used during the experiments (Table 6). 


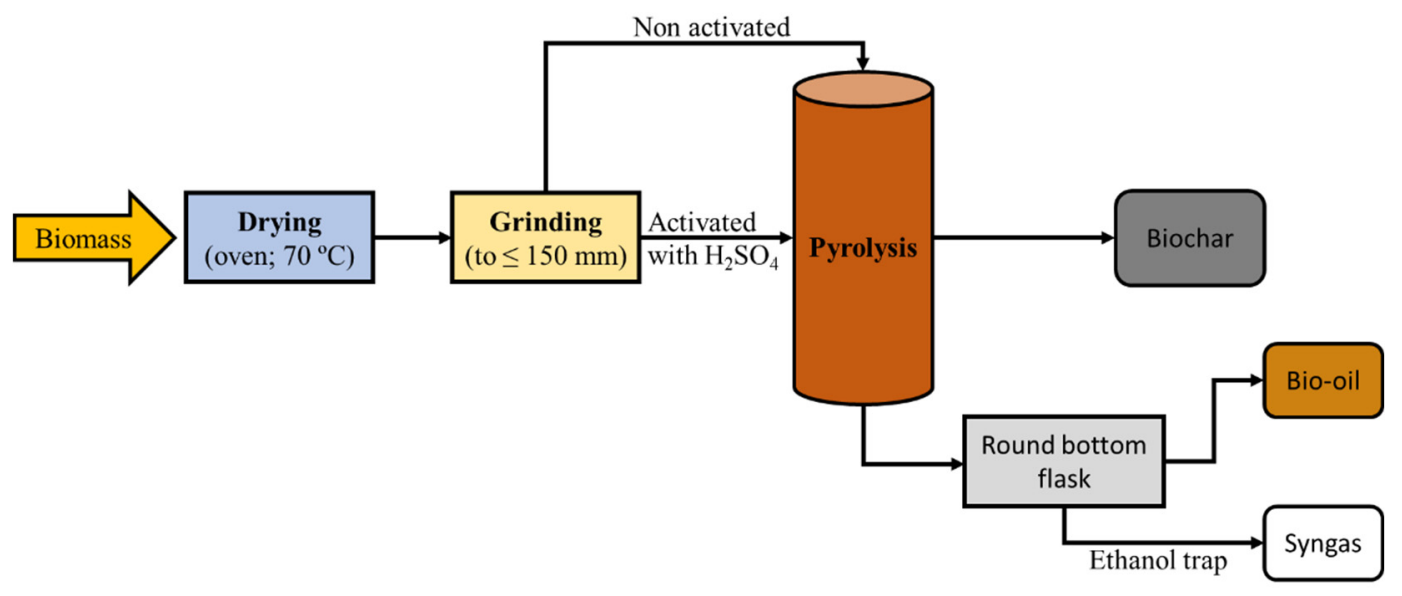

Figure 6. Process scheme for biomass pyrolysis.

Table 6. Pyrolysis conditions for olive stones (OS).

\begin{tabular}{|c|c|c|c|c|}
\hline Pyrolysis & Raw Material & $\begin{array}{c}\mathrm{T} \\
\left({ }^{\circ} \mathrm{C}\right)\end{array}$ & $\begin{array}{c}\mathrm{H}_{\text {ramp }} \\
\left({ }^{\circ} \mathrm{C} \cdot \mathrm{min}^{-1}\right)\end{array}$ & $\begin{array}{c}\text { Ar Flow } \\
\left(\mathrm{mL} \cdot \mathrm{min}^{-1}\right)\end{array}$ \\
\hline 1 & $\mathrm{OS}+\mathrm{H}_{2} \mathrm{SO}_{4}$ & 600 & 10 & 150 \\
\hline 2 & $\mathrm{OS}+\mathrm{H}_{2} \mathrm{SO}_{4}$ & 500 & 10 & 150 \\
\hline 3 & $\mathrm{OS}+\mathrm{H}_{2} \mathrm{SO}_{4}$ & 400 & 10 & 150 \\
\hline 4 & $\mathrm{OS}+\mathrm{H}_{2} \mathrm{SO}_{4}$ & 400 & 5 & 150 \\
\hline 5 & $\mathrm{OS}+\mathrm{H}_{2} \mathrm{SO}_{4}$ & 400 & 20 & 150 \\
\hline 6 & $\mathrm{OS}+\mathrm{H}_{2} \mathrm{SO}_{4}$ & 400 & 10 & 150 \\
\hline 7 & $\mathrm{OS}+\mathrm{H}_{2} \mathrm{SO}_{4}$ & 400 & 20 & 300 \\
\hline 8 & $\mathrm{OS}+\mathrm{H}_{2} \mathrm{SO}_{4}$ & 400 & 20 & 50 \\
\hline 9 & $\mathrm{OS}+\mathrm{H}_{2} \mathrm{SO}_{4}$ & 600 & 10 & 150 \\
\hline 10 & OS & 600 & 10 & 150 \\
\hline 11 & OS & 500 & 10 & 150 \\
\hline 12 & OS & 400 & 10 & 150 \\
\hline 13 & OS & 400 & 20 & 150 \\
\hline 14 & OS & 400 & 20 & 50 \\
\hline 15 & OS & 400 & 5 & 150 \\
\hline 16 & OS & 400 & 5 & 50 \\
\hline 17 & OS & 400 & 5 & 300 \\
\hline
\end{tabular}

\subsection{Bio-Oil Characterisation}

The liquid phase was recovered by transferring it from the two-neck flask of the pyrolytic equipment to a previously tared round bottom flask,. After that, to remove the remaining residue from the bottom of the two-neck flask, a few microliters of acetone were introduced and poured into the round bottom flask. Subsequently, bio-oil was taken to a rotary evaporator (Heidolph, Schwabach, Germany) to evaporate the acetone and obtain pure bio-oil.

A qualitative analysis of the bio-oil composition from pyrolysis was performed with a TSQ8000 mass spectrometer (Thermo Fisher Scientific, Waltham, MA, USA) coupled to a triple quadrupole gas chromatograph (GC-MS) equipped with an autosampler. A Zebron ZB-5MS (Phenomenex, CA, USA) column ( $30 \mathrm{~m} \times 0.25 \mathrm{~mm} \times 0.25 \mu \mathrm{m} ; 5 \%$ phenylarylene, $95 \%$ dimethylpolysiloxane) and $\mathrm{N}_{2}$ as carrier gas were used. The analyses were carried out under the following conditions: $50{ }^{\circ} \mathrm{C}$ initial temperature, $7^{\circ} \mathrm{C} \cdot \mathrm{min}^{-1}$ heating ramp for $30 \mathrm{~min}$, and final temperature $310^{\circ} \mathrm{C}$.

The identification of the peaks was performed using the database of the Quan Browser tool of the XCalibur software (Thermo Fisher Scientific, Waltham, MA, USA). To limit the number of compounds, several factors were taken into account: relative area of the 
compound greater than 1, match probability of the compound in the database greater than $40 \%$, and occurrence of the compound in a greater number of samples.

\subsection{Biochar Characterisation}

\subsubsection{Thermogravimetric Analysis}

The thermogravimeter with which this analysis was carried out was a SDT Q600 electrobalance (TA Instruments, Inc., New Castle, DE, USA), which has a sensitivity of $+/-0.5 \mu \mathrm{g}$. The system responsible for the generation of heat was a vertical furnace that allows a maximum pyrolysis temperature of $1200^{\circ} \mathrm{C}$ to be reached.

The raw material (OS) was treated at a heating ramp of $6{ }^{\circ} \mathrm{C} \cdot \mathrm{min}^{-1}$ up to $800{ }^{\circ} \mathrm{C}$, with a constant flow of $100 \mathrm{~mL} \mathrm{Ar} \cdot \mathrm{min}^{-1}$. This treatment was carried out until the complete decomposition of the organic matter, which was then burned in air, obtaining only inorganic ash.

\subsubsection{Fourier-Transform Infrared Spectroscopy (FTIR)}

A Nicolet TM iSTM5 FTIR Fourier transform infrared spectrometer (Thermo Fisher Scientific, Waltham, MA, USA) was used to characterise the feedstock and all biochars. This homogenised feedstock was compacted in a uniaxial press under pressure.

For transmission measurements, pellets were prepared using potassium bromide $(\mathrm{KBr})$ as diluent, with a final sample concentration of $5 \mathrm{wt} . \%$, and spectra were recorded in the $500-4000 \mathrm{~cm}^{-1}$ wavenumber range.

\subsubsection{BET Specific Surface}

The BET method was used to calculate the specific surface area (SBET). A Gemini V-2365/ / V.1.00 adsorption equipment (Micromeritics Instrument Corporation, Norcross, GA, USA) was used. The biochars were previously degassed at $150{ }^{\circ} \mathrm{C}$ for $2 \mathrm{~h}$ under a $\mathrm{N}_{2}$ atmosphere.

\subsection{Esterification Reaction}

The esterification reactions of olive stones, whether pre-treated (impregnated) with $\mathrm{H}_{2} \mathrm{SO}_{4}$ or not, were carried out in a stirred tank batch reactor $(25 \mathrm{~cm}$ height, $12 \mathrm{~cm}$ diameter), equipped with a temperature regulator and a gas condenser (Liebeg refrigerant cooled with water at room temperature) at $60^{\circ} \mathrm{C}$ for $30 \mathrm{~min}$.

The mixture was heated at $60{ }^{\circ} \mathrm{C}$ for $30 \mathrm{~min}$ by means of a Fibroman- $\mathrm{C}$ heating mantle (J.P. SELECTA, Barcelona, Spain) connected to a temperature controller. Two additional openings were used to extract the sample and introduce the thermocouple, which continuously measured the temperature.

Before esterification, all biochars, except biochars obtained from Pyrolyses 1, 2, and 6 (Table 6), were subjected to activation with sulphuric acid. Similar to the pre-treatment of the raw material (Section 3.1.1), the activation of the biochars was carried out by impregnation of $1 \mathrm{~g}$ of biochar with $1 \mathrm{~mL}$ of sulphuric acid (98 wt.\%). The conditions under which the esterifications were carried out were: $10 \mathrm{~g}$ oleic acid, $17.2 \mathrm{~g}$ methanol (1:15 oleic acid to methanol molar ratio), and $1 \mathrm{~g}$ biochar. These conditions were selected from previous studies available in the literature [33].

Finally, the interesting products were obtained in the organic phase, which was subjected to two determinations. The first was the measurement of its acid index, and the second was the determination of the fatty acid methyl esters (FAME) by gas chromatographymass spectroscopy in the TSQ8000 mass spectrometer (Thermo Fisher Scientific, Waltham, MA, USA) described in Sections 3.5.1 and 3.5.2.

\subsubsection{Acid Index}

Before the esterification started, it was important to know the acid index of the oleic acid, as the reduction of its value indicates the extent of the esterification reaction and allows the calculation of its yield. UNE-EN 14104:2003 was followed to determine the 
acidity of oleic acid and the esterification product. A detailed description of this procedure can be found in [34].

\subsubsection{Gas Chromatography-Mass Spectroscopy}

The percentage of different FAME in the samples was determined by gas chromatography using methyl heptadecanoate as the internal standard. A HP 5890 series II gas chromatograph (Hewlett Packard, Palo Alto, CA, USA) equipped with a SP2380 capillary column (Sigma-Aldrich, St Louis, MO, USA) [60 $\mathrm{m} \times 0.25 \mathrm{~mm}$ internal diameter $\times 0.25 \mu \mathrm{m}$ film thickness] was used. The column temperature was set at $185^{\circ} \mathrm{C}$ and then the temperature program was increased to $220^{\circ} \mathrm{C}$ with a heating ramp of $3{ }^{\circ} \mathrm{C} \mathrm{min}{ }^{-1}$. The injection was operated in splitless mode, with injector and detector temperatures of $210^{\circ} \mathrm{C}$ and $250^{\circ} \mathrm{C}$, respectively. The FAMEs were identified by mass spectrometry by comparing the spectra with those of the database for this type of compound (Wiley, NIST).

\section{Conclusions}

Thermogravimetric analysis showed that OS have a low percentage of lignin. The FTIR spectrum of the $\mathrm{OS}+\mathrm{H}_{2} \mathrm{SO}_{4}$ feedstock did not show differences in spectral bands compared to that of the OS feedstock, but did show a much lower intensity of the bands. The most suitable conditions to obtain the highest biochar yield from $\mathrm{OS}+\mathrm{H}_{2} \mathrm{SO}_{4}$ were $400{ }^{\circ} \mathrm{C}$, $20{ }^{\circ} \mathrm{C} \cdot \mathrm{min}^{-1}$ and $150 \mathrm{~mL} \mathrm{Ar} \cdot \mathrm{min}^{-1}$. The optimal conditions to obtain the highest bio-oil yield from OS were $400{ }^{\circ} \mathrm{C}, 5^{\circ} \mathrm{C} \cdot \mathrm{min}^{-1}$ and $50 \mathrm{~mL} \mathrm{Ar} \cdot \mathrm{min}^{-1}$. The highest specific surface area (approximately $400 \mathrm{~m}^{2} / \mathrm{g}$ ) was obtained in the biochar from the pyrolysis at $600{ }^{\circ} \mathrm{C}$ from OS $+\mathrm{H}_{2} \mathrm{SO}_{4}$. The FTIR spectra of the biochars obtained from $\mathrm{OS}+\mathrm{H}_{2} \mathrm{SO}_{4}$ and $\mathrm{OS}$ did not show noticeable differences. However, increasing the pyrolysis temperature decreases the intensity of the bands. The use of biochar from OS as catalyst in the esterification reaction showed better yield compared to the biochar from $\mathrm{OS}+\mathrm{H}_{2} \mathrm{SO}_{4}$. The pyrolysis conditions in terms of biochar characteristics did not affect the esterification yield.

Author Contributions: Conceptualisation, P.Á.-M.; methodology, P.Á.-M.; formal analysis, F.J.S.-B., T.J.B.d.H.-L., P.Á.-M. and J.F.G.-M.; investigation, F.J.S.-B. and T.J.B.d.H.-L.; resources, P.Á.-M.; writing—original draft preparation, F.J.S.-B. and J.F.G.-M.; writing—review and editing, J.F.G.-M.; supervision, P.Á.-M. and J.F.G.-M.; project administration, P.Á.-M.; funding acquisition, P.Á.-M. All authors have read and agreed to the published version of the manuscript.

Funding: This research was funded by the European Union under grant LIFE 13-Bioseville ENV/1113, and by the FEDER funds through the CARBOENERGY project (FEDER INNTERCONECTA 2018 call).

Data Availability Statement: The data presented in this study are available on request from the corresponding author. The data are not publicly available due to confidentiality agreements with the funding companies.

Conflicts of Interest: The authors declare no conflict of interest.

\section{References}

1. García Martín, J.F.; Cuevas, M.; Feng, C.H.; Álvarez Mateos, P.; Torres García, M.; Sánchez, S. Energetic valorisation of olive biomass: Olive-tree pruning, olive stones and pomaces. Processes 2020, 8, 511. [CrossRef]

2. Donner, M.; Radić, I. Innovative circular business models in the olive oil sector for sustainable mediterranean agrifood systems. Sustainability 2021, 13, 2588. [CrossRef]

3. Sánchez, F.; San Miguel, G. Improved fuel properties of whole table olive stones via pyrolytic processing. Biomass Bioenergy 2016, 92, 1-11. [CrossRef]

4. Rodríguez, G.; Lama, A.; Rodríguez, R.; Jiménez, A.; Guillén, R.; Fernández-Bolaños, J. Olive stone an attractive source of bioactive and valuable compounds. Bioresour. Technol. 2008, 99, 5261-5269. [CrossRef]

5. Martín Lara, M.A.; Hernáinz, F.; Calero, M.; Blázquez, G.; Tenorio, G. Surface chemistry evaluation of some solid wastes from olive-oil industry used for lead removal from aqueous solutions. Biochem. Eng. J. 2009, 44, 151-159. [CrossRef]

6. Fernández Bolaños, J.; Felizón, B.; Heredia, A.; Rodríguez, R.; Guillén, R.; Jiménez, A. Steam-explosion of olive stones: Hemicellulose solubilization and enhancement of enzymatic hydrolysis of cellulose. Bioresour. Technol. 2001, 79, 53-61. [CrossRef] 
7. Cuevas, M.; García-Martín, J.F.; Bravo, V.; Sánchez, S. Ethanol production from olive stones through liquid hot water pre-treatment, enzymatic hydrolysis and fermentation. Influence of enzyme loading, and pre-treatment temperature and time. Fermentation 2021, 7, 25. [CrossRef]

8. Merino, M.R.; Guijarro Rodríguez, J.; Fernández Martínez, F.; Santa Cruz Astorqui, J. Viability of using olive stones as lightweight aggregate in construction mortars. Rev. Constr. 2017, 16, 431-438. [CrossRef]

9. Harina de Semilla de Aceituna Premio a la Innovación en Sial Paris-Elayo. Available online: https://www.elayo.es/harina-desemilla-de-aceituna-premio-a-la-innovacion-en-sial/ (accessed on 27 October 2021).

10. AIMPLAS and OLIPE Use Olive Stones to Develop a New Sustainable Plastic Material for Oil Product Packaging I Plateforme des Acteurs Européens de L'économie Circulaire. Available online: https://circulareconomy.europa.eu/platform/fr/goodpractices / aimplas-and-olipe-use-olive-stones-develop-new-sustainable-plastic-material-oil-product-packaging (accessed on 27 October 2021).

11. Won Seo, M.; Hon Lee, S.; Nam, H.; Lee, D.; Tokmurzin, D.; Wang, S.; Park, Y.-K. Recent advances of thermochemical conversieon processes for biorefinery. Bioresour. Technol. 2022, 343, 126109. [CrossRef]

12. Collard, F.X.; Blin, J. A review on pyrolysis of biomass constituents: Mechanisms and composition of the products obtained from the conversion of cellulose, hemicelluloses and lignin. Renew. Sustain. Energy Rev. 2014, 38, 594-608. [CrossRef]

13. Bhattacharjee, N.; Baran Biswas, A. Pyrolysis of orange bagasse: Comparative study and parametric influence on the product yield and their characterization. J. Environ. Chem. Eng. 2019, 7, 102903. [CrossRef]

14. Guo, J.; Zheng, L.; Li, Z.; Zhou, X.; Cheng, S.; Zhang, L.; Zhang, Q. Effects of various pyrolysis conditions and feedstock compositions on the physicochemical characteristics of cow manure-derived biochar. J. Clean. Prod. 2021, 311, 127458. [CrossRef]

15. Basu, P. Pyrolysis and Torrefaction, 1st ed.; Elsevier: Amsterdam, The Netherlands, 2010; ISBN 9780123749888.

16. Sánchez Borrego, F.J.; Álvarez Mateos, P.; García Martín, J.F. Biodiesel and other value-added products from bio-oil obtained from agrifood waste. Processes 2021, 9, 797. [CrossRef]

17. Bradley, D.; Hektor, B.; Wild, M.; Deutmeyer, M.; Schowenberg, P.P.; Hess, J.R.; Shankar Tumuluru, J.; Bradburn, K. Low cost, log distance biomass supply chains. In Task 40: Sustainable International Bioenergy Trade; Goh, C.S., Junginger, M., Eds.; IEA Bioenergy: Paris, France, 2013; pp. 1-65.

18. Álvarez-Mateos, P.; García-Martín, J.F.; Guerrero-Vacas, F.J.; Naranjo-Calderón, C.; Barrios, C.C.; Pérez Camino, M.C.; Barrios, C.C. Valorization of a high-acidity residual oil generated in the waste cooking oils recycling industries. Grasas Y Aceites 2019, 40 , e335. [CrossRef]

19. Roy, M.; Mohanty, K. Valorization of de-oiled microalgal biomass as a carbon-based heterogeneous catalyst for a sustainable biodiesel production. Bioresour. Technol. 2021, 337, 125424. [CrossRef]

20. Sun, Y.; Gao, B.; Yao, Y.; Fang, J.; Zhang, M.; Zhou, Y.; Chen, H.; Yang, L. Effects of feedstock type, production method, and pyrolysis temperature on biochar and hydrochar properties. Chem. Eng. J. 2014, 240, 574-578. [CrossRef]

21. Islam, M.K.; Rehman, S.; Guan, J.; Lau, C.Y.; Tse, H.Y.; Yeung, C.S.; Leu, S.Y. Biphasic pretreatment for energy and carbon efficient conversion of lignocellulose into bioenergy and reactive lignin. Appl. Energy 2021, 303, 117653. [CrossRef]

22. Laurenza, A.G.; Losito, O.; Casiello, M.; Fusco, C.; Nacci, A.; Pantone, V.; D'Accolti, L. Valorization of cigarette butts for synthesis of levulinic acid as top value-added chemicals. Sci. Rep. 2021, 11, 15775. [CrossRef]

23. Hasanin, M.S.; Kassem, N.; Hassan, M.L. Preparation and characterization of microcrystalline cellulose from olive stones. Biomass Convers. Biorefinery 2021. [CrossRef]

24. Yang, H.; Yan, R.; Chen, H.; Lee, D.H.; Zheng, C. Characteristics of hemicellulose, cellulose and lignin pyrolysis. Fuel 2007, 86, 1781-1788. [CrossRef]

25. Alshuiael, S.M.; Al-Ghouti, M.A. Multivariate analysis for FTIR in understanding treatment of used cooking oil using activated carbon prepared from olive stone. PLoS ONE 2020, 15, e0232997. [CrossRef]

26. Bartocci, P.; D'Amico, M.; Moriconi, N.; Bidini, G.; Fantozzi, F. Pyrolysis of olive stone for energy purposes. Energy Procedia 2015, 82, 374-380. [CrossRef]

27. Salimi, M.; Salehi, Z.; Heidari, H.; Vahabzadeh, F. Production of activated biochar from Luffa cylindrica and its application for adsorption of 4-nitrophenol. J. Environ. Chem. Eng. 2021, 9, 105403. [CrossRef]

28. Zhao, L.; Zheng, W.; Mašek, O.; Chen, X.; Gu, B.; Sharma, B.K.; Cao, X. Roles of phosphoric acid in biochar formation: Synchronously improving carbon retention and sorption capacity. J. Environ. Qual. 2017, 46, 393-401. [CrossRef] [PubMed]

29. Cao, F.; Schwartz, T.J.; McClelland, D.J.; Krishna, S.H.; Dumesic, J.A.; Huber, G.W. Dehydration of cellulose to levoglucosenone using polar aprotic solvents. Energy Environ. Sci. 2015, 8, 1808-1815. [CrossRef]

30. Kudo, S.; Goto, N.; Sperry, J.; Norinaga, K.; Hayashi, J.I. Production of levoglucosenone and dihydrolevoglucosenone by catalytic reforming of volatiles from cellulose pyrolysis using supported ionic liquid phase. ACS Sustain. Chem. Eng. 2017, 5, 1132-1140. [CrossRef]

31. Comba, M.B.; Tsai, Y.; Sarotti, A.M.; Mangione, M.I.; Suárez, A.G.; Spanevello, R.A. Levoglucosenone and its new applications: Valorization of cellulose residues. Eur. J. Org. Chem. 2018, 5, 590-604. [CrossRef]

32. Wu, L.; Wan, W.; Shang, Z.; Gao, X.; Kobayashi, N.; Luo, G.; Li, Z. Surface modification of phosphoric acid activated carbon by using non-thermal plasma for enhancement of $\mathrm{Cu}(\mathrm{II})$ adsorption from aqueous solutions. Sep. Purif. Technol. 2018, 197, 156-169. [CrossRef] 
33. Ben-Youssef, C.; Chávez-Yam, A.; Zepeda, A.; Rivera, J.M.; Rincón, S. Simultaneous esterification/transesterification of waste cooking oil and Jatropha curcas oil with MOF-5 as a heterogeneous acid catalyst. Int. J. Environ. Sci. Technol. 2021, 18, 3313-3326. [CrossRef]

34. García Martín, J.F.; Carrión Ruiz, J.; Torres García, M.; Feng, C.H.; Álvarez Mateos, P. Esterification of free fatty acids with glycerol within the biodiesel production framework. Processes 2019, 7, 832. [CrossRef] 